\title{
Trends in the prevalence of autoimmune thyroiditis in the leading private health-care provider in Poland
}

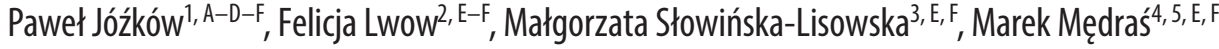 \\ ${ }^{1}$ Division of Sports Medicine, University School of Physical Education, Wrocław, Poland \\ 2 Department of Health Promotion, University School of Physical Education, Wrocław, Poland \\ ${ }^{3}$ Division of Nutrition, University School of Physical Education, Wrocław, Poland \\ ${ }^{4}$ Division of Sports Medicine, University School of Physical Education, Wrocław, Poland \\ ${ }^{5}$ Department of Endocrinology, Diabetology and Isotope Treatment, Wroclaw Medical University, Poland \\ A - research concept and design; $\mathrm{B}$ - collection and/or assembly of data; $\mathrm{C}$ - data analysis and interpretation; \\ $D$ - writing the article; $E$ - critical revision of the article; $F$ - final approval of article
}

Address for correspondence

Paweł Józków

E-mail: pjozkow@wp.pl

Funding sources

None declared

Conflict of interest

None declared

\section{Acknowledgements}

We are thankful to dr Krzysztof Kurek and dr Inga Długon for their goodwill in performing the investigation. The extraction of the data from the LUXMED database would not have been possible without the diligent work of Rafał Paczuski.

Received on April 29, 2015

Revised on November 05, 2015

Accepted on December 03, 2015

\begin{abstract}
Background. Autoimmune thyroiditis (AT) is one of the most common endocrine disorders affecting a significant percent of the population, especially women. It may have serious and long-lasting consequences. The etiology of AT is multifactorial and it arises from an interplas between environmental and genetic factors. Tendencies in AT prevalence and incidence are unclear. In Poland there are no national registers covering the data on AT prevalence.

Objectives. The aim of the investigation was to assess changes in diagnosing AT in the largest chain of outpatient medical centers in Poland.

Material and methods. We compared fregnancy at which AT and hypothyroidism diagnoses were made during endocrinology consultations in the period 2006-2013. The data was extracted from the database of LUXMED (part of BUPA).

Results. Within 8 years, the prevalence of newly diagnosed AT dropped from 10.4\% to 4.8\% ( $p<0.001)$ alongside with a decrease in the prevalence of newly diagnosed hypothyroidism from $17.8 \%$ to $7.7 \%$ $(p<0.00001)$. AT was widespread in young women aged 20-39. There were relatively more cases in the southern areas of Poland.

Conclusions. The analyzed data does not support a hypothesis indicating a growing incidence of AT in the last years. Detailed epidemiological studies would be helpful in designing screening strategies for patients with this common disorder.
\end{abstract}

Key words: prevalence, hypothyroidism, autoantibodies, autoimmune thyroiditis

DOI

10.17219/acem/60862

Copyright

Copyright by Author(s)

This is an article distributed under the terms of the

Creative Commons Attribution Non-Commercial License

(http://creativecommons.org/licenses/by-nc-nd/4.0/) 
Autoimmune thyroiditis (AT) is a common disorder of the thyroid gland. It is usually diagnosed when thyroid autoantibodies (TPOAbs/TGAbs) are detected in patients with hypothyroidism or goiter. It is assumed that thyroid autoimmunity may affect $2 \%$ of males and more than $10 \%$ of females, while thyroid dysfunction due to AT occurs in $2 \%$ of the population. ${ }^{1}$

The etiology of AT is complex and not fully explained. ${ }^{2}$ The disease arises as a result of an interplay between genetic and environmental factors. Among genes that may contribute to AT one can count: HLA-DR3, HLA-DR 31 Arg74, HLA-DR pocket-sequence variant and non-MHC genes e.g. CD40, CTLA-4, PTPN22, thyreoglobulin and TSH receptor genes. The environmental influences comprise: smoking, stress, iodine intake, medications, bacterial and viral infections, irradiation, pollutants and pregnancy. It is emphasized that epigenetic effects may play an important role in thyroid autoimmunity. ${ }^{3,4}$

Common experience suggests that the incidence of AT is increasing. Although some studies point to such a trend in the incidence and prevalence of AT, real patterns of the disorder are not easy to trace and compare. ${ }^{5-8}$

The aim of the present study was to evaluate whether there was any change in the prevalence of AT in a sample of Polish population consulted in LUXMED centers in the period 2006-2013.

\section{Material and methods}

In order to assess the prevalence of AT a search of LUXMED database was performed. LUXMED (part of BUPA) is the leading private healthcare provider in Poland offering services through a chain of 140 company's medical centers. The company's services are offered primarily to people paying a monthly fee (corporate clients), but single, paid consultations are provided as well. It is estimated that the company's database comprised around 230,000 patients (mainly corporate) in 2006 and $1,200,000$ (including 800,000 corporate) in 2013 . The annual number of consultations in the company's clinics exceeds 3,000,000 including more than 155,000 endocrinology consultations. It can be assumed that LUXMED corporate patients are professionally active (the majority between 20-50, practically all under 65), work in the private sector (or are self-employed), earn more than average, their jobs do not involve much physical activity and are not significant exposed to chemicals/toxins/radiation. Most of them reside in cities/towns rather than in villages.

The main search term used in the present investigation was E06.3 (autoimmune thyroiditis, AT). The diagnosis of AT required the presence of autoantibodies (TPOAbs/ TGAbs) in association with goiter/thyroid atrophy/typical ultrasound findings or hypothyroidism. It was made solely during endocrinology consultations. Each entry was counted once for a specific patient. The acquired data was compared with the number of endocrinology consultations in the given year and the number of patients in whom the diagnosis of hypothyroidism (E03 with exclusion of E03.2, E03.5 and E03.3) was made. There were no other exclusion criteria used. Both corporate and onetime patients were counted. The data was available for the period 2006-2013.

Statistical analysis was performed using PQStat (v. 1.4.2.324). The number of patients with the diagnosis of AT in consecutive years was assessed with the $\chi^{2}$ test and the $\chi^{2}$ test for the trend. The Pearson's coefficient of correlation and the Spearman's rank correlation coefficient were also employed. The prevalence of men and women with AT in respective age groups were compared with the Mann-Whitney U test. The prevalence of patients with AT diagnosed in different centers in Poland in respective age groups were compared with Kruskal-Wallis test. The associations between sex and age groups for patients with AT were analyzed with the $\chi^{2}$ test and the $\chi^{2}$ test for the trend. A p-value less than 0.05 was considered significant and less than 0.01 as highly significant.

\section{Results}

In the studied period a highly significant trend in the prevalence of AT was observed $\left(\chi^{2}=0,85, \mathrm{df}=1\right.$, $\mathrm{p}<0.00013)$ and there was a highly significant association $\left(\chi^{2}=908,17, \mathrm{df}=7, \mathrm{p}<0.0001\right)$ between the number of patients diagnosed with AT and specific years (Fig. 1, Table 1).

Between 2006 and 2007 a steep decrease in AT frequency from $10.4 \%$ to $6.5 \%$ was noted. In the next two years the frequencies were respectively above 5 and $3 \%$.

Table 1. Numbers of patients diagnosed with autoimmune thyroiditis (E06.3) and hypothyroidism (E03) and relative frequencies of prevalence (at endocrinology consultations EC) in the consecutive years

\begin{tabular}{|c|c|c|c|c|c|}
\hline Year & $\begin{array}{c}E 06.3 \\
(n)\end{array}$ & $\begin{array}{c}E 03 \\
(n)\end{array}$ & $\begin{array}{c}E C \\
(n)\end{array}$ & $\begin{array}{c}\text { E06.3/EC } \\
(\%)\end{array}$ & $\begin{array}{c}\text { E03/EC } \\
(\%)\end{array}$ \\
\hline 2006 & 656 & 1127 & 6326 & 10.37 & 17.82 \\
\hline 2007 & 953 & 1104 & 14686 & 6.49 & 7.52 \\
\hline 2008 & 999 & 1362 & 18662 & 5.35 & 7.30 \\
\hline 2009 & 2482 & 5952 & 70216 & 3.53 & 8.48 \\
\hline 2010 & 4885 & 10961 & 84687 & 5.77 & 12.94 \\
\hline 2011 & 5716 & 10786 & 109117 & 5.24 & 9.88 \\
\hline 2012 & 6144 & 11148 & 127567 & 4.82 & 8.74 \\
\hline 2013 & 7540 & 11942 & 155442 & 4.85 & 7.68 \\
\hline
\end{tabular}


Fig. 1. Prevalence of autoimmune thyroiditis (E06.3) and hypothyroidism (E03) diagnosed during endocrinology consultations in the consecutive years

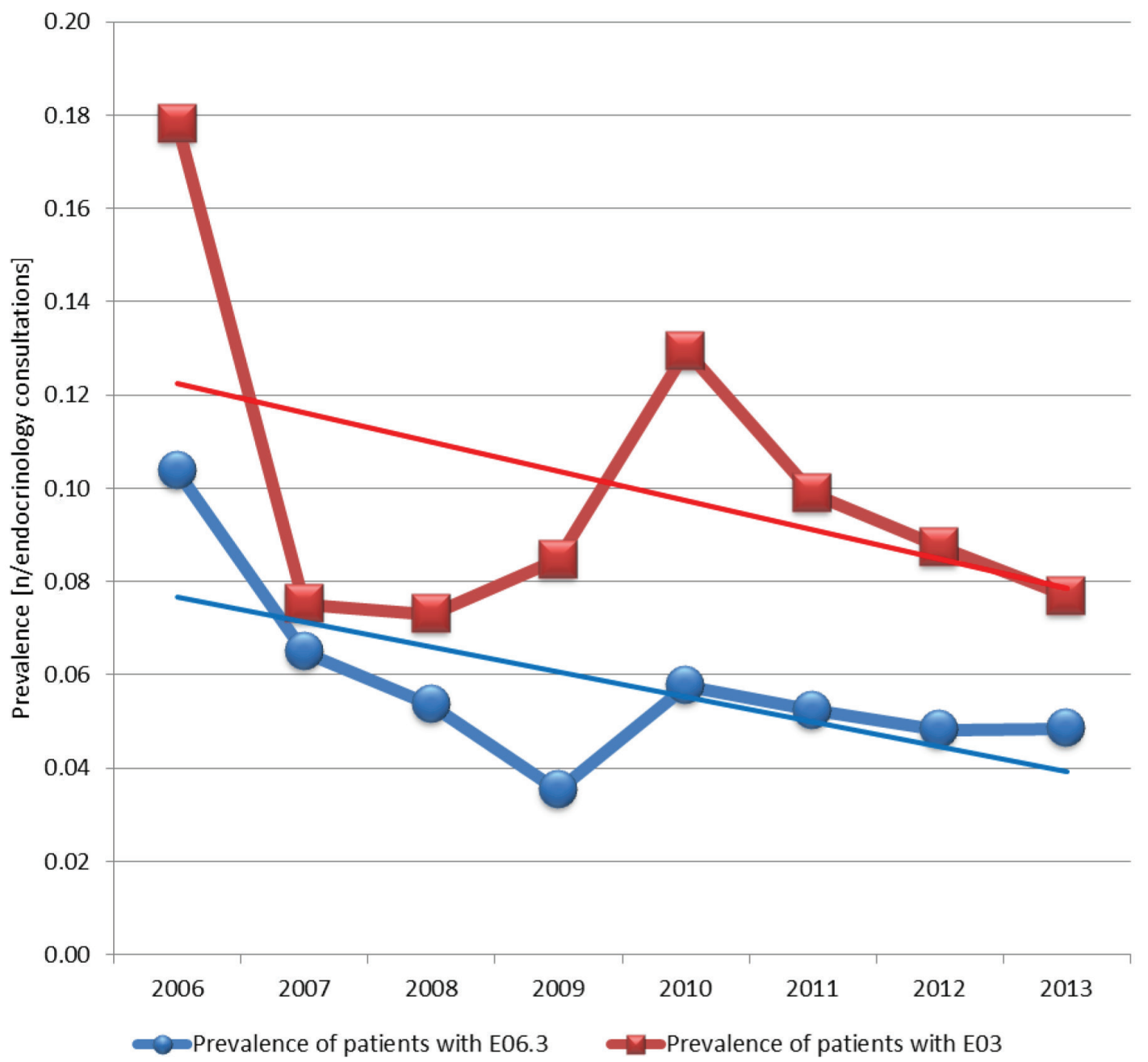

In 2007 a transient increase of AT frequency to $5.8 \%$ was followed by a decrease to the level below $5 \%$ in the last years.

The analysis of correlation confirmed the presence of linear $(\mathrm{r}=-0.9816, \mathrm{p}<0.00001)$ and rank correlation $(\mathrm{r}=1.0000, \mathrm{p}<0.00001)$ between the number of AT patients and the consecutive years.

A highly significant trend $\left(\chi^{2}=476.64, \mathrm{df}=1, \mathrm{p}<0.00001\right)$ and association $\left(\chi^{2}=2657.79, \mathrm{df}=7, \mathrm{p}<0.0001\right)$ was also found for the diagnosis of hypothyroidism (E03). In 2006 the prevalence of hypothyroid patients was very high, close to $18 \%$, however it dropped to $7.6 \%$ in 2007 . In the following years the number of patients diagnosed with hypothyroidism at endocrinology consultations fluctuated between 7.3 and $12.9 \%$ and settled at $7.7 \%$ in 2013 . The analysis of correlation coefficients showed linear $(\mathrm{r}=-0.9433, \mathrm{p}=0.0004)$ and $\operatorname{rank}(\mathrm{r}=0.9524, \mathrm{p}=0.0003)$ associations between the number of patients with hypothyroidism and the consecutive years.

Endocrinologists diagnosed AT most often in subjects aged 30-39. The second group in which AT prevalence was high was the group between 20 and 29 years of age. The diagnosis was made significantly more often in women than in men in 2 age groups: $20-29(\mathrm{p}=0.0005)$ and $30-39$ $(p=0.0186)$. In other age groups there were no considerable differences of AT prevalence between sexes (Fig. 2).

A comparison of data from 4 distinguished areas of the country: north (Olsztyn, Trójmiasto, Szczecin), south (Katowice, Tychy, Opole, Kraków, Dębica, Zabierzów), middle (Warszawa, Łódź, Aleksandrów Łódzki, Bydgoszcz) and west (Wrocław, Poznań, Gorzów Wielkopolski) revealed geographical differences of the prevalence of AT in all age groups apart from patients under 19 and aged 30-39 (Fig. 3).

The number of AT in the age group 20-29 was lowest in the north and highest in the south of Poland ( $p=0.0007)$. To the contrary, the prevalence of AT was lowest in the south of Poland in patients aged 40-49, 50-59 and over 60 (Table 2, Fig. 4).

There was a statistically significant difference of the prevalence of AT depending on the area of the country $\left(\chi^{2}=104.93, \mathrm{df}=3, \mathrm{p}<0.0001\right)$. The diagnosis was made most frequently in the west (0.0544) and least frequently - in the south of Poland (0.043). 


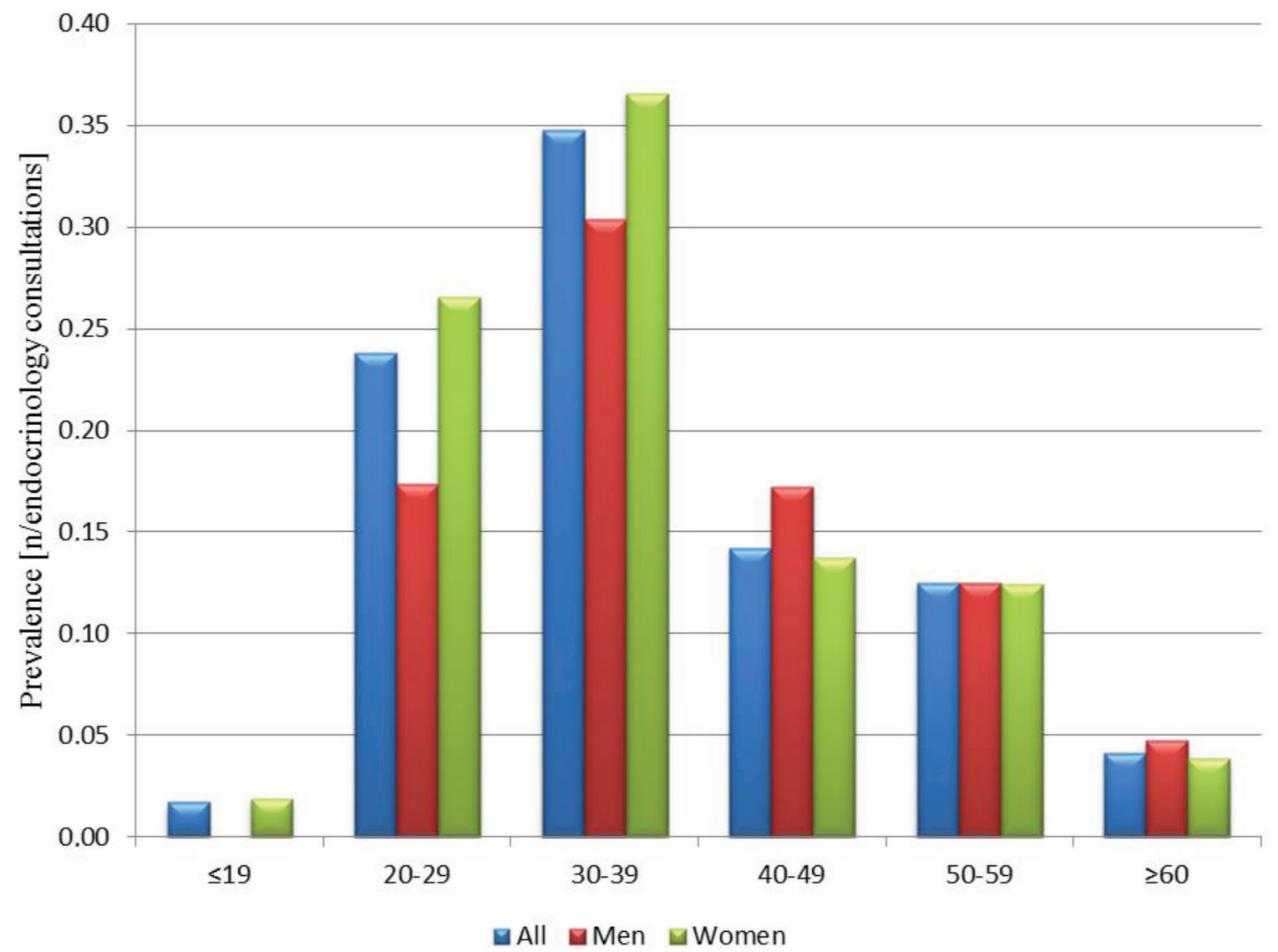

Fig. 2

Frequencies

of patients

diagnosed with

E06.3 in age/sex groups

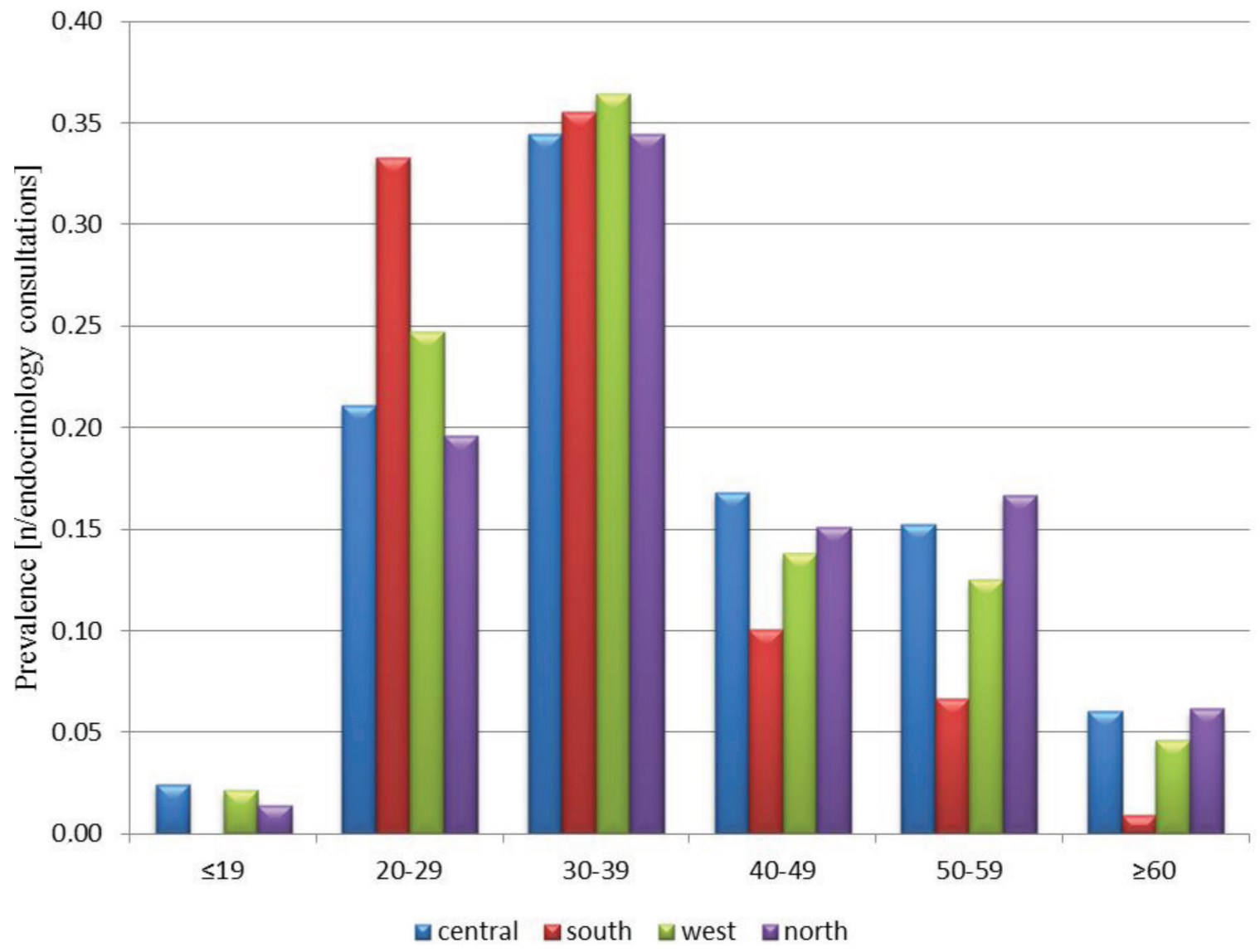

Fig. 3. Prevalence of patients diagnosed with E06.3 in 4 distinguished regions (data presented for age groups) 


\section{Discussion}

Prevalence of the thyroid autoantibody positivity is relatively high worldwide. It is well-known that in iodinesufficient areas there is a higher rate of AT prevalence than in iodine-deficient ones (9). Iodine intake is probably one of the most important factors that affects thyroid autoimmunity and the incidence of AT.10

In a random sample of general, euthyroid population living in Holland ( $n=2703$ ) the prevalence of the TPOAbs positive cases was $8.4 \%{ }^{11}$ In Denmark among 4649 randomly selected subjects between 18 and 65 years of age $13.1 \%$ were TPOAbs positive and $18.1 \%$ had increased concentrations of either TPO or TG autoantybodies. ${ }^{12}$ In the United States, TPOAbs were positive in $11.3 \%$ and TGAbs in $10.4 \%$ in a population sample of 13,344 subjects. In Japan among 1818 adults $31.4 \%$ of women and $17.7 \%$ of men were positive for TgAbs or TPOAbs. ${ }^{13}$ In another study from the same country presence of TPOAbs or TGAbs was reported in $12.8 \%$ of the studied cases. ${ }^{14}$ A very similar number $(12.4 \%$ TPOAb positivity) was noted also by Australian authors. ${ }^{15}$ In India TPOAbs were detected in more than $13 \%$ subjects from a group of 4409 adults and 22\% from a sample of 5376 adults. ${ }^{16,17}$ Generally, TPOAbs are present in $12-26 \%$ of euthyroid subjects, more often in women. ${ }^{18}$

These observations are in line with the data on the prevalence of hypothyroidism. In Europe the prevalence of undiagnosed and diagnosed hypothyroidism is estimated to be between 3.05 and $4.94 \%{ }^{8}$ In the United States $4.6 \%$ of the population has hypothyroidism. ${ }^{19}$ In Japan overt or subclinical hypothyroidism is noted in $6.5 \%$ of the population, while in India subclinical hypothyroidism is diagnosed in $15.9 \%$ of men and $21.4 \%$ of women (overall prevalence 19.3\%). ${ }^{13,17}$

In Poland information on thyroid function/thyroid autoimmunity was gathered, e.g. in 4190/1594 subjects over 55 years of age in the framework of the PolSenior study. In this cross-sectional investigation $17.4 \%$ of subjects were TPOAb positive and 7.9\% could be classified as hypothyroid. The prevalence of TPOAb seropositivity was higher in females than in males (27 vs 15\%) (20).

As expected, also in our sample more women than men were diagnosed with AT (and hypothyroidism, data not presented). Such results were concordant with observations of hypothyroidism from Poland and other countries. ${ }^{8,19,20}$

It is more difficult to say whether there is a rising trend in AT occurrence over the years. Such an impression emerges from an analysis of studies conducted in the United Kingdom, Slovenia and Denmark. ${ }^{7}$ In Australia thyroid autoantybodies were detected in 9.8 of women and $2.8 \%$ of men in 1975 and in 1981 these ratios changed into respectively 17 and 6.8\%.7,21 A hypothesis of an increasing incidence of thyroid autoimmunity is also supported by results of an Italian investigation performed in a rural community of $1411 / 1148$ subjects. In this study a clear rise in the number of thyroid autoantybodies positive cases was noted between 1995 and 2010. TPOAbs positivity rose from 12.6 to $19.5 \%(\mathrm{p}<0.001)$ and AT from 3.5 to $14.5 \%(\mathrm{p}<0.0001) .{ }^{10}$ In concordance with the above findings are observations of Danish cohorts from 19971998 and 2004-2005. The positivity for TPOAbs changed from 14.3 to $23.8 \%$ and for TGAbs from 13.7 to $19.9 \%$ after introducing mandatory iodization of salt. ${ }^{22}$ Also in Poland, obligatory iodine prophylaxis (which started in 1997) was associated with a clear increase in the percent of TPOAbs positive individuals from 3.8 to $11.8 \%$. Over the period of 10 years (1989-1999) the prevalence of hypothyroidism ratios in the city of Kraków increased insignificantly in women and men from respectively 1.4 to $2.1 \%$ and from 0 to $0.3 \% .^{23}$

Our data does not confirm increasing trends in AT occurrence. They correspond to some extent with the results of a comparison of two population surveys (33,917/49,180 individuals) performed in 1995-1997 and 2006-2008 in Norway. The Scandinavian authors noted a decrease in the prevalence of overt hypothyroidism in women from 0.75 to $0.12 \%$ (84\%) and in men from 0.21 to $0.12 \%(43 \%)$. The prevalence of subclinical hypothyroidism changed from 3.0 to $1.1 \%(64 \%)$ in women and from 2.1 to $1.0 \%$ (54\%) in men. Conversely, the prevalence of treated hypothyroidism among women increased by $60 \%$ from 5.0 to $8.0 \%$ in men by $100 \%$ from 1.0 to $2.0 \%$. It must be admitted that the prevalence of all forms of hypothyroidism did not change remarkably, as it was found in $9 \%$ of women and $3 \%$ of men. ${ }^{24}$

The strength of the present study is a relatively high number of observations made in clinics from all over the country. Unlike other medical conditions (e.g. neoplasms, contagious diseases) thyroid pathology is not covered by any public database of a national scale. According to the report of the Central Statistical Office (http://www.stat. gov.pl/gus/5840_12706_ENG_HTML.htm), the number of endocrinology consultations in outpatient clinics in Poland (public sector) was around 4,000,000 in 2012. The consultations covered by our study (127 567 in 2012) would constitute $3.2 \%$ of the whole number of endocrinology consultations.

The data was acquired from an ethnically homogenous population from an area with sufficient iodine intake dating back to $1997 .{ }^{25}$ Although the criteria of AT (or hypothyroidism) could not be imposed, it should be stressed that the diagnoses were made only by endocrinologists.

A limitation of the investigation is the fact that the majority of the subjects from the sample live in urban environments, are employed and under 65 . The lifestyle parameters may not reflect the situation of the general population. One may assume that the economical status of the consulted patients is higher than average. The latter may be associated with e.g. diet/eating habits. The presented results could not be controlled for age, smoking status, pregnancy, concomitant ailments or received medications either. 
Table 2. Prevalence of patients diagnosed with E06.3 in the 4 distinguished areas.

\begin{tabular}{|c|c|c|c|c|c|c|c|c|c|}
\hline \multirow{2}{*}{\multicolumn{2}{|c|}{$\begin{array}{l}\text { Age of patients/avea of } \\
\text { the country }\end{array}$}} & \multicolumn{7}{|c|}{ Descriptive statistics } & \multirow{3}{*}{$\begin{array}{c}\text { Kruskal-Wallis } \\
\text { test }\end{array}$} \\
\hline & & \multirow{2}{*}{$\begin{array}{l}\text { mean } \\
0.0259\end{array}$} & \multirow{2}{*}{$\begin{array}{l}\text { standard } \\
\text { deviation } \\
0.0202\end{array}$} & \multirow{2}{*}{$\begin{array}{l}\text { minimum } \\
0.0000\end{array}$} & \multirow{2}{*}{$\begin{array}{l}\text { lower } \\
\text { quartile } \\
0.0151\end{array}$} & \multirow{2}{*}{$\begin{array}{l}\text { median } \\
0.0244\end{array}$} & \multirow{2}{*}{$\begin{array}{l}\text { upper } \\
\text { quartile } \\
0.0383\end{array}$} & \multirow{2}{*}{$\begin{array}{l}\text { maximum } \\
0.0741\end{array}$} & \\
\hline & central & & & & & & & & \\
\hline \multirow{3}{*}{$\leq 19$} & south & 0.0488 & 0.1691 & 0.0000 & 0.0000 & 0.0000 & 0.0236 & 1.0000 & \multirow{3}{*}{$\begin{array}{c}H=7.56 \\
p=0.0559\end{array}$} \\
\hline & west & 0.0324 & 0.0367 & 0.0000 & 0.0000 & 0.0214 & 0.0501 & 0.1250 & \\
\hline & north & 0.0717 & 0.2121 & 0.0000 & 0.0000 & 0.0144 & 0.0462 & 1.0000 & \\
\hline \multirow{4}{*}{$20-29$} & central & 0.2399 & 0.2050 & 0.0000 & 0.1644 & 0.2109 & 0.2469 & 1.0000 & \multirow{4}{*}{$\begin{array}{c}H=17.08 \\
p=0.0007\end{array}$} \\
\hline & south & 0.3710 & 0.2731 & 0.0000 & 0.2000 & 0.3333 & 0.4615 & 1.0000 & \\
\hline & west & 0.2537 & 0.1874 & 0.0000 & 0.1970 & 0.2474 & 0.3000 & 1.0000 & \\
\hline & north & 0.1761 & 0.1159 & 0.0000 & 0.1111 & 0.1962 & 0.2615 & 0.4000 & \\
\hline \multirow{4}{*}{$30-39$} & central & 0.3392 & 0.1619 & 0.0000 & 0.3041 & 0.3446 & 0.3902 & 1.0000 & \multirow{4}{*}{$\begin{array}{c}H=0.31 \\
p=0.9571\end{array}$} \\
\hline & south & 0.3339 & 0.2412 & 0.0000 & 0.1818 & 0.3555 & 0.4923 & 1.0000 & \\
\hline & west & 0.3680 & 0.2263 & 0.0000 & 0.2929 & 0.3645 & 0.3930 & 1.0000 & \\
\hline & north & 0.3563 & 0.2473 & 0.0000 & 0.2632 & 0.3447 & 0.3775 & 1.0000 & \\
\hline \multirow{4}{*}{$40-49$} & central & 0.1851 & 0.1240 & 0.0000 & 0.1388 & 0.1682 & 0.2077 & 0.6667 & \multirow{4}{*}{$\begin{array}{c}H=13.12 \\
p=0.0044\end{array}$} \\
\hline & south & 0.1161 & 0.1703 & 0.0000 & 0.0000 & 0.1008 & 0.1538 & 1.0000 & \\
\hline & west & 0.1650 & 0.1265 & 0.0000 & 0.0984 & 0.1381 & 0.1913 & 0.5000 & \\
\hline & north & 0.1420 & 0.1154 & 0.0000 & 0.0000 & 0.1508 & 0.1905 & 0.4444 & \\
\hline \multirow{4}{*}{$50-59$} & central & 0.1457 & 0.0702 & 0.0000 & 0.1241 & 0.1527 & 0.1766 & 0.3333 & \multirow{4}{*}{$\begin{array}{l}H=21.48 \\
p=0.0001\end{array}$} \\
\hline & south & 0.0968 & 0.1809 & 0.0000 & 0.0000 & 0.0667 & 0.0946 & 1.0000 & \\
\hline & west & 0.1394 & 0.1200 & 0.0000 & 0.1057 & 0.1250 & 0.1600 & 0.5000 & \\
\hline & north & 0.1562 & 0.1397 & 0.0000 & 0.1111 & 0.1667 & 0.2000 & 0.6667 & \\
\hline \multirow{3}{*}{$\geq 60$} & central & 0.0642 & 0.0507 & 0.0000 & 0.0244 & 0.0605 & 0.0926 & 0.1923 & \multirow{3}{*}{$\begin{array}{l}H=12.05 \\
p=0.0072\end{array}$} \\
\hline & south & 0.0334 & 0.0576 & 0.0000 & 0.0000 & 0.0091 & 0.0435 & 0.3000 & \\
\hline & west & 0.0414 & 0.0390 & 0.0000 & 0.0000 & 0.0459 & 0.0524 & 0.1594 & \\
\hline
\end{tabular}




\section{Conclusions}

It seems there is a downward trend in the prevalence of autoimmune thyroiditis (AT) in privately insured patients in Poland over the years. Whether this is true for the whole population needs to be confirmed.

Young female patients aged 20-39 suffer from AT most often. There are relatively more cases in the southern areas of the country.

\section{References}

1. Hashimoto's Thyroiditis [database on the Internet]. ENDOCRINE EDUCATION Inc, South Dartmouth, MA 02748. 2013 [cited 27.12.2013]. Available from: http://www.thyroidmanager.org/chapter/hashimotos-thyroiditis/.

2. Weetman AP. The immunopathogenesis of chronic autoimmune thyroiditis one century after hashimoto. Eur Thyroid J. Jan;1(4):243-250.

3. Eschler DC, Hasham A, Tomer Y. Cutting edge: The etiology of autoimmune thyroid diseases. Clin Rev Allergy Immunol. 2011; 41(2):190-197.

4. Tomer Y. Mechanisms of autoimmune thyroid diseases: From genetics to epigenetics. Annu Rev Pathol. 2014;9:147-156.

5. Benvenga S, Trimarchi F. Changed presentation of Hashimoto's thyroiditis in North-Eastern Sicily and Calabria (Southern Italy) based on a 31-year experience. Thyroid. 2008;18(4):429-441.

6. Leese GP, Flynn RV, Jung RT, Macdonald TM, Murphy MJ, Morris AD. Increasing prevalence and incidence of thyroid disease in Tayside, Scotland: The Thyroid Epidemiology Audit and Research Study (TEARS). Clin Endocrinol (Oxf). 2008;68(2):311-316.

7. McLeod DS, Cooper DS. The incidence and prevalence of thyroid autoimmunity. Endocrine. 2012;42(2):252-265.

8. Garmendia Madariaga A, Santos Palacios S, Guillen-Grima F, Galofre JC. The Incidence and Prevalence of Thyroid Dysfunction in Europe: A Meta-analysis. J Clin Endocrinol Metab. 2014;1:jc20132409.

9. Lind P, Langsteger W, Molnar M, Gallowitsch HJ, Mikosch P, Gomez I. Epidemiology of thyroid diseases in iodine sufficiency. Thyroid. 1998;8(12):1179-1783.

10. Aghini Lombardi F, Fiore $\mathrm{E}$, Tonacchera $\mathrm{M}$, et al. The effect of voluntary iodine prophylaxis in a small rural community: The Pescopagano survey 15 years later. J Clin Endocrinol Metab. 2013;98(3):10311039.

11. Roos $A$, Links TP, de Jong-van den Berg LT, Gans RO, Wolffenbuttel BH, Bakker SJ. Thyroid peroxidase antibodies, levels of thyroid stimulating hormone and development of hypothyroidism in euthyroid subjects. Eur J Intern Med. 2010;21(6):555-559.
12. Pedersen IB, Knudsen N, Jorgensen T, Perrild H, Ovesen L, Laurberg $P$. Thyroid peroxidase and thyroglobulin autoantibodies in a large survey of populations with mild and moderate iodine deficiency. Clin Endocrinol (Oxf). 2003;58(1):36-42.

13. Kasagi K, Takahashi N, Inoue G, Honda T, Kawachi Y, Izumi Y. Thyroid function in Japanese adults as assessed by a general health checkup system in relation with thyroid-related antibodies and other clinical parameters. Thyroid. 2009;19(9):937-944.

14. Takeda K, Mishiba M, Sugiura H, Nakajima A, Kohama M, Hiramatsu $S$. Evaluated reference intervals for serum free thyroxine and thyrotropin using the conventional outliner rejection test without regard to presence of thyroid antibodies and prevalence of thyroid dysfunction in Japanese subjects. Endocr J. 2009;56(9):1059-1066.

15. O'Leary PC, Feddema PH, Michelangeli VP, et al. Investigations of thyroid hormones and antibodies based on a community health survey: The Busselton thyroid study. Clin Endocrinol (Oxf). 2006;64(1):97-104.

16. Unnikrishnan AG, Kalra S, Sahay RK, Bantwal G, John M, Tewari N. Prevalence of hypothyroidism in adults: An epidemiological study in eight cities of India. Indian J Endocrinol Metab. 2013;17(4):647-652.

17. Marwaha RK, Tandon N, Ganie MA, et al. Status of thyroid function in Indian adults: two decades after universal salt iodization. J Assoc Physicians India. 2012;60:32-36.

18. Prummel MF, Wiersinga WM. Thyroid peroxidase autoantibodies in euthyroid subjects. Best Pract Res Clin Endocrinol Metab. 2005;19(1):1-15.

19. Hollowell JG, Staehling NW, Flanders WD, et al. Serum TSH, T(4), and thyroid antibodies in the United States population (1988 to 1994): National Health and Nutrition Examination Survey (NHANES III). J Clin Endocrinol Metab. 2002;87(2):489-499.

20. Bar-Andziak E, Milewicz A, Jedrzejuk D, Arkowska A, Mieszczanowicz U, Krzyzanowska-Swiniarska B. Thyroid dysfunction and thyroid autoimmunity in a large unselected population of elderly subjects in Poland - the 'PolSenior' multicentre crossover study. Endokrynol Pol. 2012;63(5):346-355.

21. Hawkins BR, Cheah PS, Dawkins RL, et al. Diagnostic significance of thyroid microsomal antibodies in randomly selected population. Lancet. 1980;15;2(8203):1057-1059.

22. Bulow Pedersen I, Knudsen N, Carle A, et al. A cautious iodization program bringing iodine intake to a low recommended level is associated with an increase in the prevalence of thyroid autoantibodies in the population. Clin Endocrinol (Oxf). 2011;15;75(1):120-126.

23. Buziak-Bereza M, Golkowski F, Szybinski Z. [Disturbances of thyroid function in adult population of the city of Cracow followed up for ten years observation]. Przeg/ Lek. 2005;62(7):676-679.

24. Asvold BO, Vatten LJ, Bjoro T. Changes in the prevalence of hypothyroidism: the HUNT Study in Norway. Eur J Endocrinol. 2013;169(5):613-620.

25. Szybinski Z. Work of the Polish Council for Control of lodine Deficiency Disorders, and the model of iodine prophylaxis in Poland. Endokrynol Pol. 2012;63(2):156-160. 